\title{
Solution Combustion Synthesis of Complex Oxide Semiconductors ${ }^{1}$
}

\author{
M. K. Hossain ${ }^{a}$, E. Kecsenovity ${ }^{b, c}$, A. Varga ${ }^{b, c}$, M. Molnár ${ }^{b, c}$, C. Janáky ${ }^{b, c}$, and K. Rajeshwar ${ }^{a, *}$ \\ ${ }^{a}$ Department of Chemistry and Biochemistry, The University of Texas at Arlington, Arlington, TX, 76109-0065 USA \\ ${ }^{b}$ MTA-SZTE, Lendület Photoelectrochemistry Research Group, Szeged, H-6720 Hungary \\ ${ }^{c}$ Department of Physical Chemistry and Materials Science, University of Szeged, Szeged, H-6720 Hungary \\ *e-mail:rajeshwar@uta.edu \\ Received April 3, 2018; in final form, May 10, 2018
}

\begin{abstract}
This is a perspective of the role that combustion synthesis, specifically solution combustion synthesis, has played in the development of ternary and quaternary metal oxide semiconductors, and materials derived from these compounds such as composites, solid solutions, and doped samples. The attributes of materials, collectively termed 'complex oxides' within the context of this discussion, are discussed in terms of their applicability in the generation of solar fuels from water splitting and $\mathrm{CO}_{2}$ reduction, and environmental pollution remediation via heterogeneous photocatalysis.
\end{abstract}

Keywords: solution combustion synthesis, solar energy conversion, hydrogen evolution, photoexcitation, synthesis variables

DOI: $10.3103 / \mathrm{S} 1061386218030032$

\section{INTRODUCTION}

Metal oxides are important from both fundamental chemistry and practical application perspectives. They occur, in the solid state, in a fascinating array of crystallographic structures and polymorphs. Both their surfaces and bulk can be chemically altered to impart striking effects on their optoelectronic, charge transport, magnetic, or catalytic properties. The library of possible materials can be expanded by variation of both cationic and anionic sub-lattices within the oxide structure [1-4]. These, in turn, lead to a wide array of application possibilities in energy conversion, energy storage, microelectronics, magnetic devices, etc. Metal oxides can be electronically conducting or insulating, and their optical transparency can be tuned to afford a class of important technological materials termed transparent, conducting oxides or TCOs. Further, they can also exhibit semiconductor behavior and be made in either $n$ - or $p$-type form. Utilization of sunlight using metal oxide semiconductors via artificial photosynthesis (to photoelectrochemically generate solar fuels) or photocatalytic degradation of environmental pollutants has attracted much attention in recent years [5-7]. Although photocatalytic degradation of pollutants has found limited commercial success, artificial photosynthesis still languishes in the research laboratory in the absence of a "magic bullet" oxide semiconductor.

Photoelectrochemical generation of solar fuels demands a rigorous (even conflicting) set of material

\footnotetext{
${ }^{1}$ The article is published in the original.
}

attributes including chemical/electrochemical robustness under irradiation, optimal optical attributes that match the solar spectrum, and exceptional bulk carrier transport and surface electrocatalytic attributes [5-7]. Furthermore, the component element(s) must be earth-abundant and non-toxic. Thus it is hardly surprising that no metal oxide has emerged so far, even after $\sim 4$ decades of research. The on-going search (the so-called Holy Grail, Ref. 8) has expanded beyond binary oxide semiconductors to ternary or even quaternary metal oxides [4]. Composites of multiple metal oxides, solid solutions of metal oxides, and doping are attractive strategies for tweaking materials attributes for photoelectrochemical and photocatalytic applications. Control of the metal oxidation state (for example, the ratio of copper in the +1 or +2 states in copper oxide) in a solution combustion synthesis (SCS) environment is another intriguing avenue in this regard. Within the context of the present article, all these materials aspects are collectively termed as "complex oxides." While precedent reviews and a monograph exist for the combustion synthesis of binary metal oxides in general [9-17], including from one of us previously [16], we are not aware of an instance where combustion synthesis-derived complex oxides have been discussed from the above perspectives. This then constitutes the main theme of the present article with examples drawn from recent work in both our laboratories in the United States and in Hungary. 
Table 1. Attributes of SCS relative to other routes for preparation of nanocrystalline metal oxide powders

\begin{tabular}{l|l|l|l}
\hline \multicolumn{1}{c|}{ Synthesis candidate } & Energy efficiency & Time efficiency & \multicolumn{1}{c}{ Comments } \\
\hline Solution combustion synthesis & Very good & Very good & Sample composition can be easily tuned \\
Hydrothermal synthesis & Very good & Moderate & - \\
Sol-gel & Good & Poor & Mild conditions \\
Ceramic & Poor & Poor & Sample usually obtained in crystalline form \\
Arc-melting and plasma & Poor & Very good & - \\
\hline
\end{tabular}

\section{SYNTHETIC ASPECTS AND MECHANISTIC UNDERSTANDING}

Where does combustion synthesis stand relative to other candidates available for the synthesis of metal oxides in nanocrystalline (powder) form? Table 1 shows relevant aspects.

It is noted, as also exemplified by the other contributions in this special volume celebrating the successes of combustion synthesis, that there are many variants of combustion synthesis. For example, spray pyrolysis has been combined with combustion synthesis for preparing TCO films [18]. Indeed, the variant commonly deployed in most works, including our own, utilizes the so-called volume solution combustion mode [19]. Figure 1 outlines the essence of this commonly-used approach.

The main handicap of the SCS approach is mostly associated with the lack of thermal control since the synthesis basically occurs in an explosive environment. Therefore, other, more controllable variants (e.g., self-propagating sol-gel combustion, Ref. 19) have been developed; see also other papers in this issue.

The other handicap is that visualization of dynamic events occurring during the SCS itself is hampered, precluding close monitoring of the reaction progress and mechanisms. There is a fertile field of opportunity here for the development of operando techniques, especially based on optical (e.g., infra-red) probes that may be profitably inserted into the SCS environment. In other variants of SCS, thermocouples have been used in the combustion tube to measure the combustion temperature and burning velocity [20]. Nonetheless, some degree of understanding of the mechanistic aspects of SCS may be gleaned by the use of thermal analysis (i.e., differential scanning calorimetry, DSC and thermogravimetric analysis, TGA) on the SCS precursors. An example is contained in Fig. 2.

A quick gauge of the ignition temperature and exothermicity of a given reaction mixture can be attained by simulating SCS using DSC-TGA. A representative DSC-TGA profile for a SCS precursor is shown in Fig. 2. Different stages in Fig. 2 (shown by dashed lines) can be identified with: (a) endothermic loss of water, (b) combustion reaction, (c) removal of carbonaceous materials, and (d) final product formation with constant mass. In Fig. 2, the DSC peak at $\sim 200^{\circ} \mathrm{C}$ confirms the exothermic nature of the reaction and concurrent loss of mass corroboates the evolution of gaseous products (cf. Fig. 1). The constant mass regime 'd' in the TGA scan (Fig. 2) reflects the refractory nature of most metal oxides. Interestingly, use of data such as those in Fig. 2 also serves to carefully delineate the temperature chosen for post-synthesis thermal anneal. This step is sometimes needed for improving the morphology of the oxide sample for the targeted application.

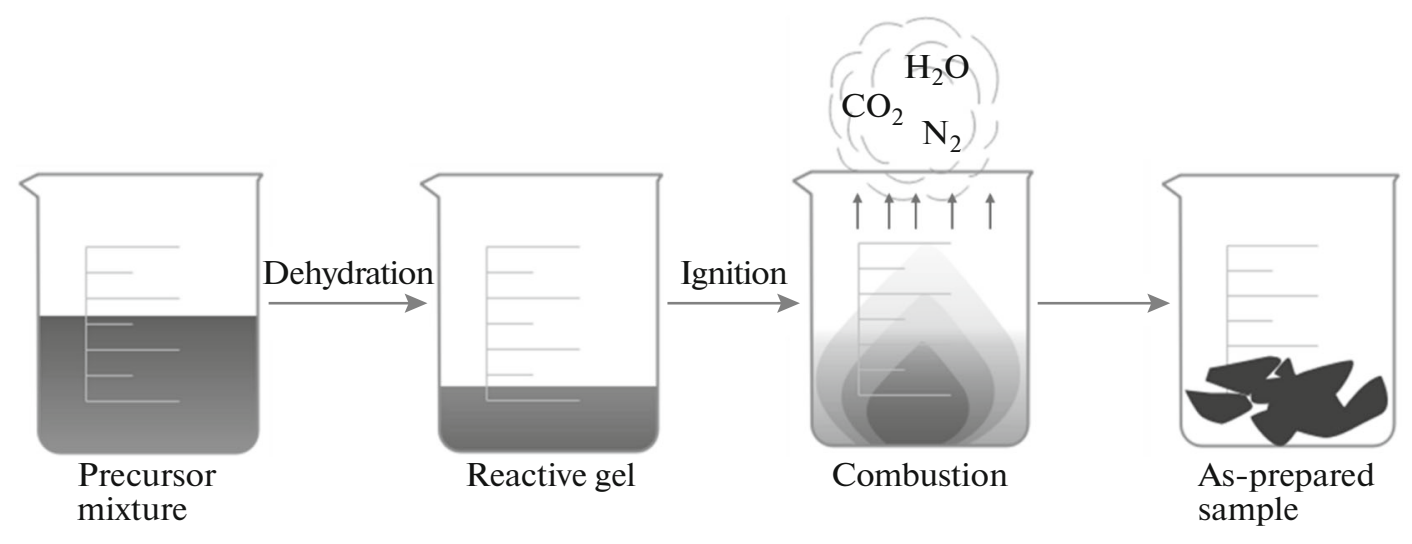

Fig. 1. Schematic of the solution combustion synthesis variant used in the studies considered here. 


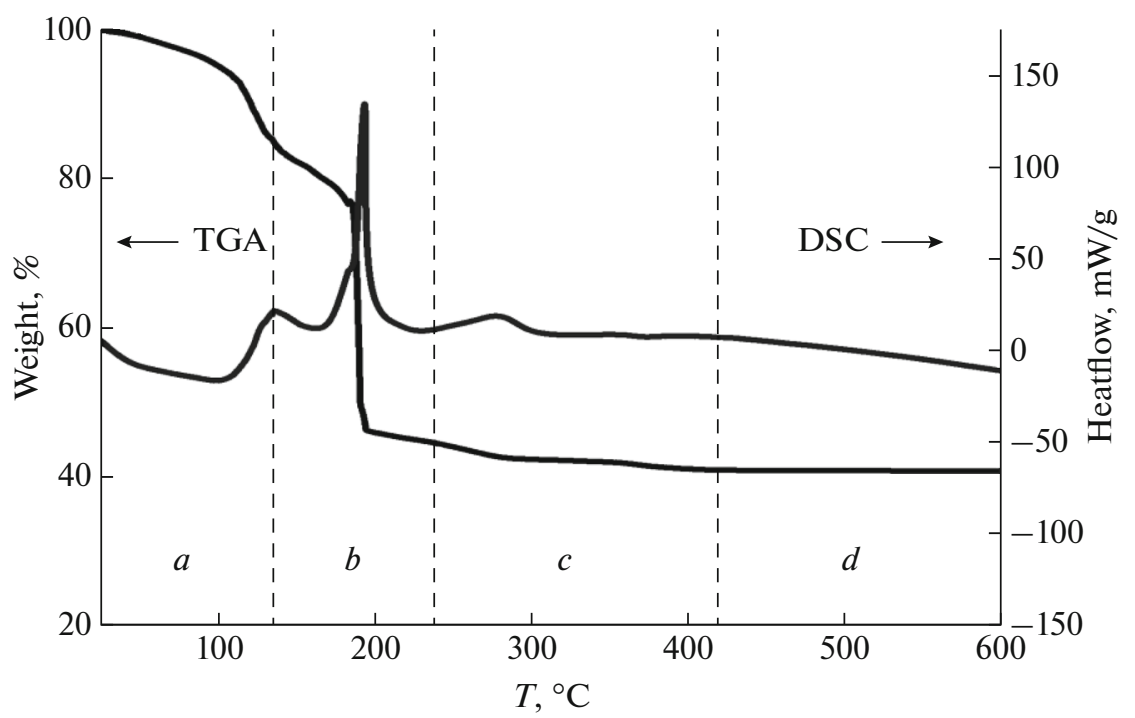

Fig. 2. Representative DSC-TGA profile for a SCS precursor metal nitrate-fuel (e.g. urea) mixture. This example is for the SCS of copper bismuth oxide where stoichiometric amounts of copper nitrate, bismuth nitrate, and urea were dissolved together in water to make the precursor mixture.

(a)

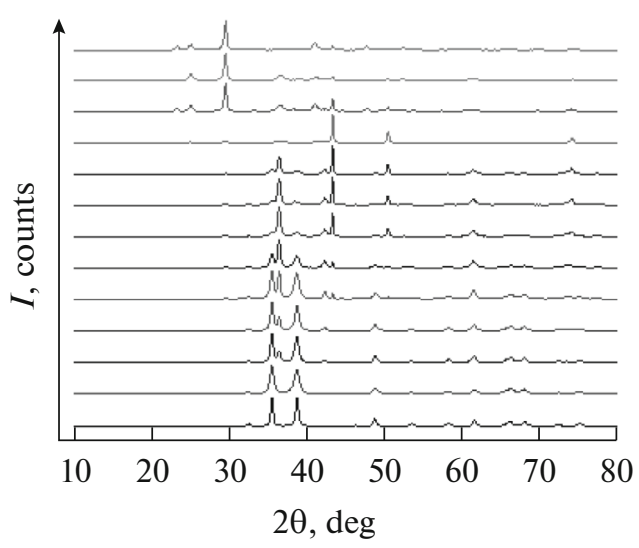

(b)

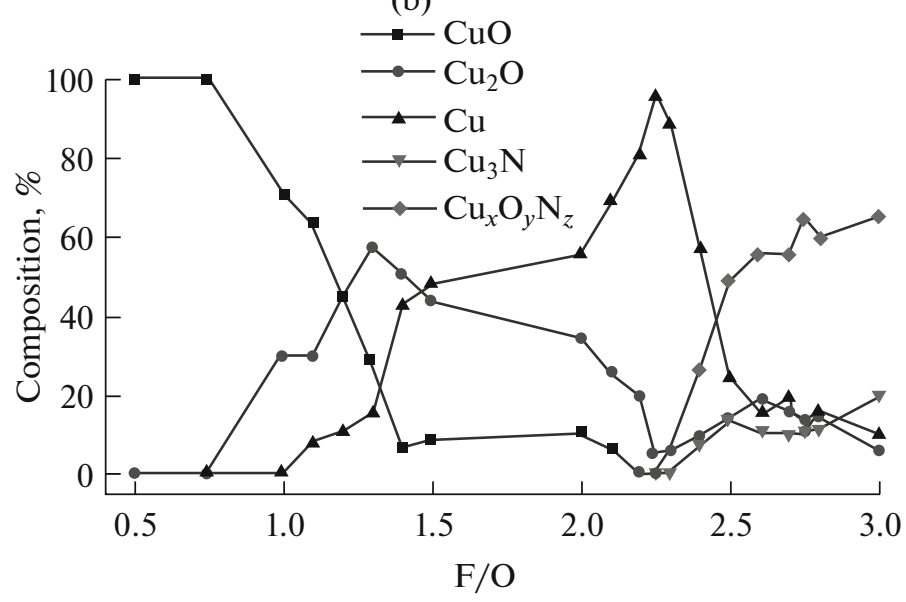

Fig. 3. (a) X-ray diffraction patterns and (b) composition of SC-synthesized $\mathrm{Cu}_{x} \mathrm{O}_{y}$ derived from precursors with different $\mathrm{F} / \mathrm{O}$ ratios.

\section{CONTROL OF THE METAL OXIDATION STATE}

The fuel/oxidizer ratio $(\mathrm{F} / \mathrm{O})$ is a versatile tool in the control of many SCS-derived sample variables, including the metal oxidation state. Figures 3 and 4 contain data demonstrating the key role of $\mathrm{F} / \mathrm{O}$. Thus a series of samples were derived from SCS where the $\mathrm{F} / \mathrm{O}$ ratio was systematically varied [from 0.5 to 4.0 , with hexamethylenetetramine (HMT) as the fuel]. The F/O ratio directly affects the redox nature of the mixture, while the flame temperature is indirectly affected. Even at the first glance there are clear changes in the series of XRD patterns (Fig. 3). The low $\mathrm{F} / \mathrm{O}$ ratio regime corresponds to the most oxidative environment, consequently the most oxidized species
$(\mathrm{CuO})$ is formed under these circumstances. With an increase of the $\mathrm{F} / \mathrm{O}$ ratio, alterations in the XRD profiles are seen (Fig. 3), with the gradual appearance of the more reduced products (i.e., $\mathrm{Cu}_{2} \mathrm{O}, \mathrm{Cu}, \mathrm{Cu}_{3} \mathrm{~N}$ ). The nitride product is somewhat surprising and the mechanistic aspects underlying its formation (see below), requires further study, beyond the scope of this discussion.

Careful inspection of the XRD patterns furnished further insights on the composition. Figure 4 compares diffraction patterns recorded for samples synthesized with four different $\mathrm{F} / \mathrm{O}$ ratios, and the position of the most relevant diffraction of the possible components is also presented. At low $\mathrm{F} / \mathrm{O}$ ratios, the $\mathrm{CuO}$ 

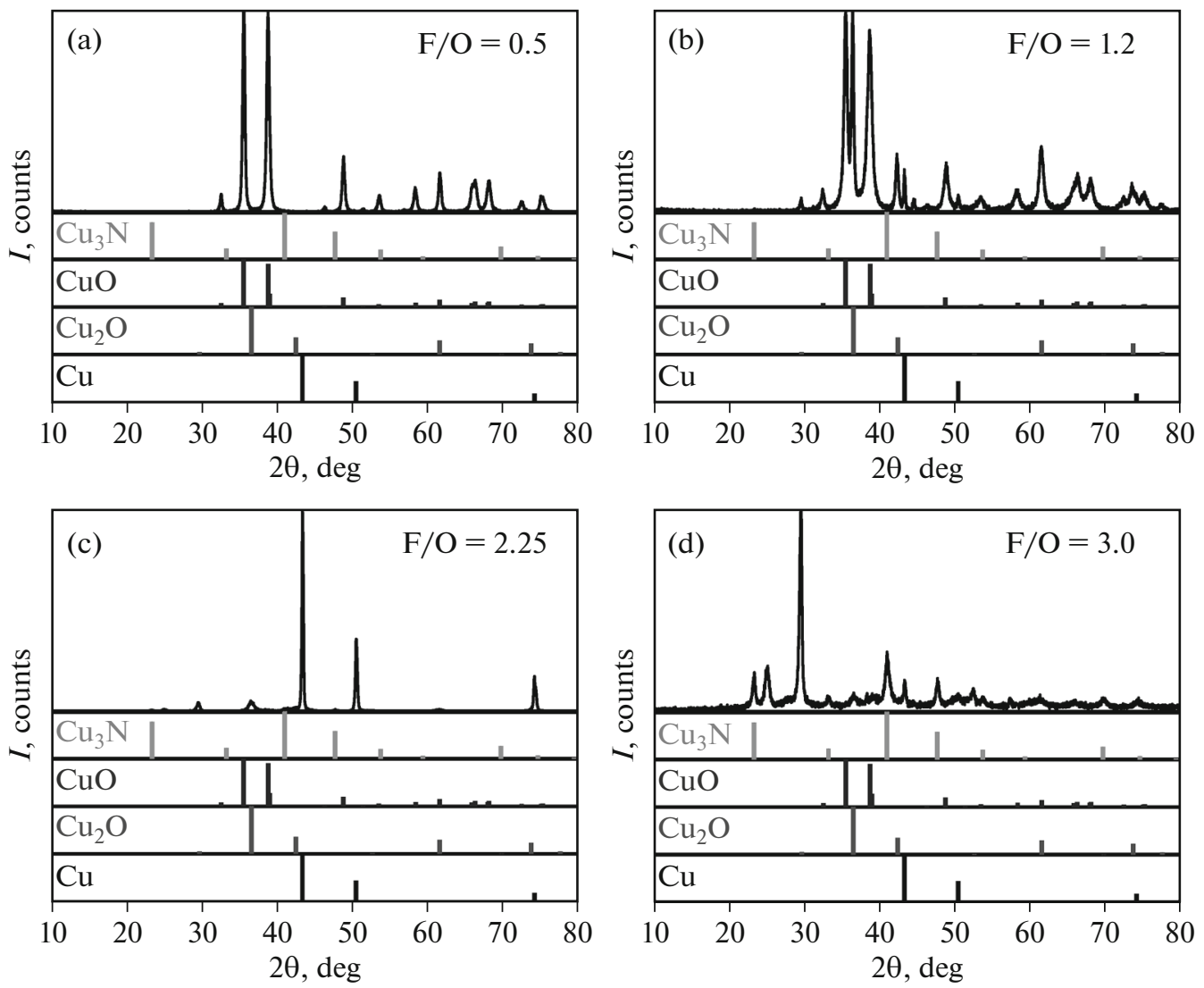

Fig. 4. XRD patterns of SC-synthesized $\mathrm{Cu}_{x} \mathrm{O}_{y}$ samples (using HMT fuel) obtained with four different $\mathrm{F} / \mathrm{O}$ ratios, together with the patterns for the four relevant reference materials (see text).

phase was formed almost exclusively. Importantly, all $\mathrm{CuO}$-related diffractions can be identified without the presence of any minority phase. With the increase of the $\mathrm{F} / \mathrm{O}$ ratio, diffractions related to the $\mathrm{Cu}_{2} \mathrm{O}$ phase appeared first, as deduced from the reflections at $2 \theta=$ $36.5,42.4$, and $61.5^{\circ}$. With further increase of the fuel content, the $\mathrm{CuO}$ phase was completely attenuated, while reflections related to metallic $\mathrm{Cu}$ developed. Finally, at very high $\mathrm{F} / \mathrm{O}$ ratios, diffractions of $\mathrm{Cu}_{3} \mathrm{~N}$ were spotted, together with the development of diffractions related to a mixed oxide-nitride phase.

To assess the role of the reducing power of the fuel, the same set of experiments was carried out with urea. Similar trends were revealed, but similar compositions were obtained at different $\mathrm{F} / \mathrm{O}$ ratios for the two systems. The higher reducing power of HMT is demonstrated in Fig. 5, where the oxide reaction product was more $\mathrm{Cu}$-rich, compared to its counterpart synthesized with urea fuel, under otherwise identical conditions. That is, the composition was skewed to a $\mathrm{Cu} / \mathrm{O}$ ratio that was somewhat less than the predicted $2: 1$ level.

\section{SCS OF TERNARY AND QUATERNARY METAL OXIDES}

A variety of binary metal oxides have been prepared via combustion synthesis. The earlier review articles cited above $[11,12,16]$ provide a summary of this corpus of studies. Table 2 provides a compilation of ternary and quaternary metal oxides that have been derived from combustion syntheses. An impressive array of oxides spanning many important crystallographic structures has been synthesized using an equally diverse range of fuels. The effect of fuel in controlling the combustion intensity and thus the temperature attained is reflected in the corresponding range of nanoparticle morphology attributes (Columns 5-7) in Table 2.

Examples of data, reflecting the influence of SCS variables on the sample attributes, are morphology although these are as yet rather sparse on ternary oxides, confined only to a limited number of them. Different fuels such as urea, glycine, carboxymethylcellulose, citric acid, DL-malic acid and mixed fuels were applied for synthesizing $\mathrm{BiVO}_{4}$ [41-43]. Use of urea or glycine showed a trace amount of $\mathrm{V}_{2} \mathrm{O}_{5}$ as impurity which was believed to be due to the lack of chelation of $\mathrm{Bi}^{3+}$ and $\mathrm{VO}_{3}^{-}$ions in the precursor mix- 

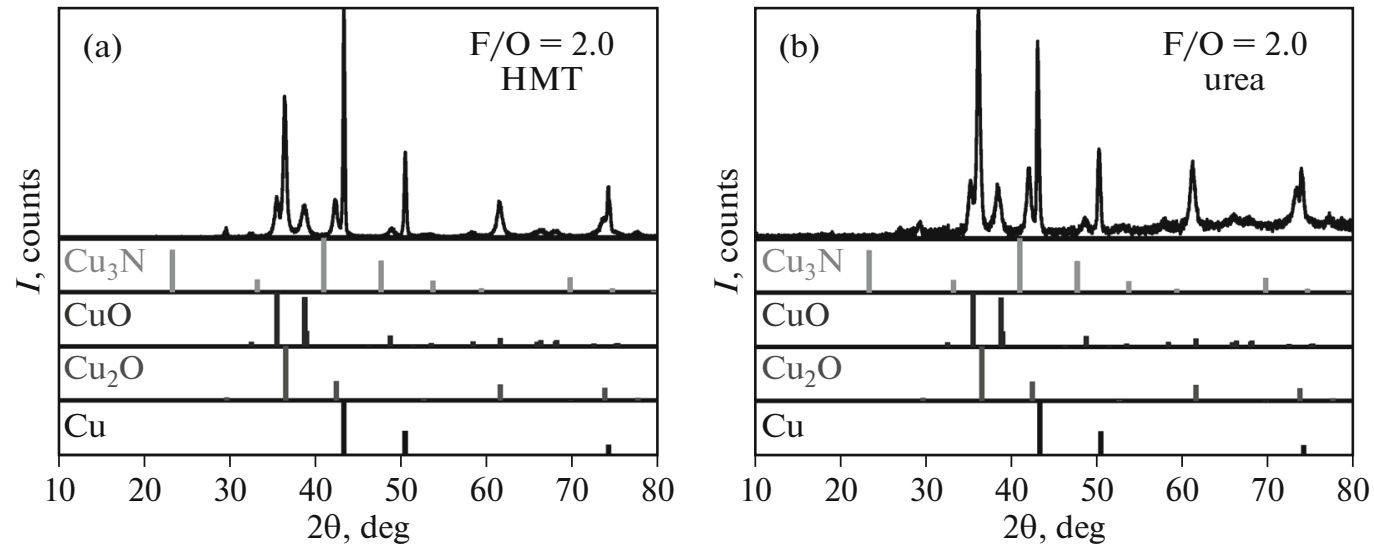

Fig. 5. XRD patterns for $\mathrm{SC}$-synthesized $\mathrm{Cu}_{x} \mathrm{O}_{y}$ samples (using $\mathrm{F} / \mathrm{O}=2.0$ ratio), obtained with two different fuels $-\mathrm{HMT}$ (a) and urea (b) - together with the patterns of the reference materials.

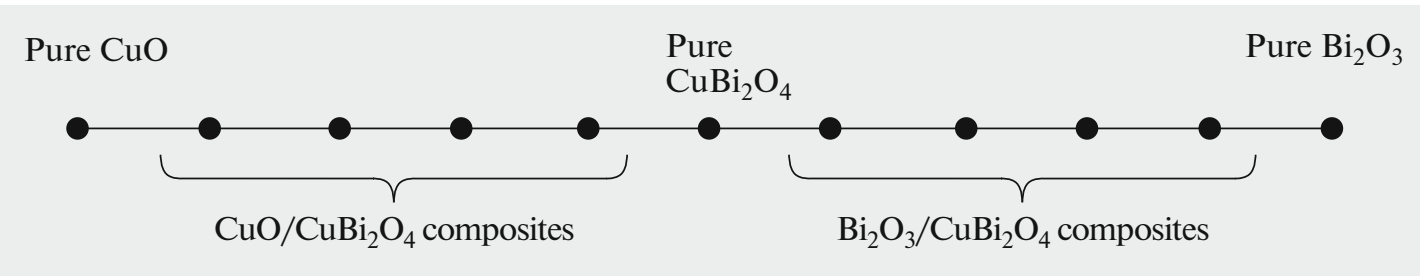

Fig. 6. Formation of ternary oxides and composites in the $\mathrm{Cu}-\mathrm{Bi}-\mathrm{O}$ system. The line format shows the composition relationships between the ternary compound and its binary oxide components. The make-up of the eight composite mixtures that were studied, is also shown on this diagram.

ture [41-43]. When citric acid, carboxymethylcellulose and DL-malic acid were used as fuel, it formed a single phase $\mathrm{BiVO}_{4}$ due to their strong chelating action maintaining a homogeneous precursor mixture [4143]. In terms of BET surface area, glycine and urea produced the lowest surface area values which can be correlated with their strong reducing power. While producing the maximum combustion temperature as a result, agglomeration of particles is an unfortunate consequence. On the other hand, use of carboxymethlycellulose or DL-malic acid led to the formation of single phase $\mathrm{BiVO}_{4}$ with higher surface areas, i.e. 3.00 and $13.86 \mathrm{~m}^{2} / \mathrm{g}$ respectively, presumably stemming their slow, controlled combustion [41].

Similarly, precursor chemistry also influences the purity of the final product. In the SCS of $\mathrm{CuWO}_{4}$, $\mathrm{ZnWO}_{4}$ and $\mathrm{Ag}_{2} \mathrm{WO}_{4}$, two different types of precursors namely $\mathrm{Na}_{2} \mathrm{WO}_{4} \cdot 2 \mathrm{H}_{2} \mathrm{O}$ and $\left(\mathrm{NH}_{4}\right)_{2} \mathrm{WO}_{4}$, were used for the tungsten source [45]. Interestingly, $\mathrm{Na}_{2} \mathrm{WO}_{4}$. $2 \mathrm{H}_{2} \mathrm{O}$ produced almost pure product while binary $\mathrm{WO}_{3-x}$ was always present as impurity when $\left(\mathrm{NH}_{4}\right)_{2} \mathrm{WO}_{4}$ was used as tungsten source [45].

The F/O ratio was found to exert a great influence on the purity and product quality in the SCS of $\mathrm{Bi}_{2} \mathrm{Ti}_{2} \mathrm{O}_{7}$ [50]. Propulsion chemistry principles teach that a maximum temperature can be achieved when the ratio is 1 (i.e. stoichiometric conditions). However, fuel-rich or fuel-lean conditions can often produce a superior product in terms of desired phase, better crystallinity, higher surface area etc. In the case of $\mathrm{Bi}_{2} \mathrm{Ti}_{2} \mathrm{O}_{7}$ with HMT as a fuel, only an amorphous product was formed when $\mathrm{F} / \mathrm{O}=1.5$ or less. However, increasing $\mathrm{F} / \mathrm{O}$ to 2.0 produced a well-crystallized material [49]. A similar trend was also found for the combustion synthesis of $\mathrm{FeAl}_{2} \mathrm{O}_{4}$ and $\mathrm{MgAl}_{2} \mathrm{O}_{4}$ [2426]. For the synthesis of $\mathrm{FeAl}_{2} \mathrm{O}_{4}$, different molar ratios of urea ( 3 to 7 ) were used; excess urea reduced the surface area and increased the particle size. However, after a certain $\mathrm{F} / \mathrm{O}$ ratio, the surface area started to increase [24].

\section{COMPOSITES OF TERNARY METAL OXIDES, DOPED SAMPLES, AND SOLID SOLUTIONS VIA SOLUTION COMBUSTION SYNTHESIS}

The distinction between composites and solid solutions relates to how two or more components are dispersed in a structural framework relative to one another. If the components are phase-separated, then the resultant framework is termed a composite. Thus in the $\mathrm{Cu}-\mathrm{Bi}-\mathrm{O}$ ternary system, composites of $\mathrm{CuBi}_{2} \mathrm{O}_{4}$ can be formed with either of its components, $\mathrm{CuO}$ or $\mathrm{Bi}_{2} \mathrm{O}_{3}$ [22]. Both neat $\mathrm{CuO}$ and $\mathrm{Bi}_{2} \mathrm{O}_{3}$ as well 
Table 2. Ternary and quaternary oxides from solution combustion synthesis and sample attributes

\begin{tabular}{|c|c|c|c|c|c|c|c|}
\hline $\begin{array}{c}\text { Entry } \\
\text { no. }\end{array}$ & Crystal class & Oxide & Fuel used & $\begin{array}{l}\text { Average } \\
\text { crystallite } \\
\text { size, nm }\end{array}$ & $\begin{array}{c}\text { TEM } \\
\text { Particle } \\
\text { size, nm }\end{array}$ & $\begin{array}{c}\text { BET } \\
\text { surface, } \\
\mathrm{m}^{2} / \mathrm{g}\end{array}$ & Refs. \\
\hline 1 & \multirow[t]{10}{*}{ Spinel } & $\mathrm{CaFe}_{2} \mathrm{O}_{4}$ & Glycine & - & 100 & 79.3 & 21 \\
\hline 2 & & $\mathrm{CuBi}_{2} \mathrm{O}_{4}$ & Urea & 35 & 300 & 1.9 & 22 \\
\hline 3 & & $\mathrm{CuFe}_{2} \mathrm{O}_{4}$ & Urea & - & $40-50$ & 40 & 23 \\
\hline 4 & & $\mathrm{FeAl}_{2} \mathrm{O}_{4}$ & Diethylamine hydrochloride and urea & 16 & - & 179.3 & 24,25 \\
\hline 5 & & $\mathrm{MgAl}_{2} \mathrm{O}_{4}$ & Glycine & 21.3 & - & 12.1 & 26 \\
\hline 6 & & $\mathrm{MgFe}_{2} \mathrm{O}_{4}$ & Urea & 18 & - & - & 27 \\
\hline 7 & & $\mathrm{MnFe}_{2} \mathrm{O}_{4}$ & Oxalyl dihydrazine & 22 & - & - & 28 \\
\hline 8 & & $\mathrm{NiFe}_{2} \mathrm{O}_{4}$ & Citric acid & - & - & - & 29 \\
\hline 9 & & $\mathrm{SnCd}_{2} \mathrm{O}_{4}$ & Citric acid & - & $10-15$ & 28 & 30 \\
\hline 10 & & $\mathrm{ZnFe}_{2} \mathrm{O}_{4}$ & Urea & - & 50 & 17 & 31 \\
\hline 11 & \multirow[t]{7}{*}{ Perovskite } & $\mathrm{GdFeO}_{3}$ & Glycine & 43 & 58 & - & 32 \\
\hline \multirow[t]{2}{*}{12} & & $\mathrm{LaFeO}_{3}$ & Citric acid & 24.1 & 24 & 25.8 & 33 \\
\hline & & & Triethylamine hydrochloride & 26.7 & - & 84.5 & 34 \\
\hline 13 & & $\mathrm{LaNiO}_{3}$ & Citric acid & 23.1 & $\sim 100$ & 15.1 & 35 \\
\hline 14 & & $\mathrm{SrTiO}_{3}$ & Glycine & 23 & 20 & 12 & 36 \\
\hline \multirow[t]{2}{*}{15} & & $\mathrm{YFeO}_{3}$ & Glycine & 50 & 50 & 6.4 & 37 \\
\hline & & & Alanine & 22 & - & 24.2 & 38 \\
\hline 16 & \multirow[t]{2}{*}{ Aurivillius } & $\mathrm{Bi}_{2} \mathrm{MoO}_{6}$ & Tartaric acid & - & $300-500$ & $<1$ & 39 \\
\hline 17 & & $\mathrm{Bi}_{2} \mathrm{WO}_{6}$ & Glycine & - & $20-30$ & 25.5 & 40 \\
\hline \multirow[t]{4}{*}{18} & \multirow[t]{4}{*}{ Scheelite } & \multirow[t]{4}{*}{$\mathrm{BiVO}_{4}$} & Citric acid or urea or glycine & - & 34 & $\sim 1$ & 41 \\
\hline & & & Citric acid and urea & 34 & $400-600$ & 1.8 & 42 \\
\hline & & & Sodium carboxymethyl-cellulose & - & $400-600$ & 3 & 43 \\
\hline & & & DL-malic acid & - & $10-20$ & 13.9 & 44 \\
\hline 19 & \multirow[t]{3}{*}{ Wolframite } & $\mathrm{CuWO}_{4}$ & Urea & 22 & - & 13.2 & 45 \\
\hline \multirow[t]{2}{*}{20} & & $\mathrm{ZnWO}_{4}$ & Urea & 32 & - & 11.9 & 45 \\
\hline & & & Sucrose & $20-30$ & $30-130$ & 19.2 & 46 \\
\hline 21 & \multirow[t]{2}{*}{ Zircon } & $\mathrm{LaVO}_{4}$ & Glycine & - & $5-80$ & 3.2 & 47 \\
\hline 22 & & $\mathrm{CeVO}_{4}$ & Oxalyl dihydrazide & - & - & 3 & 48 \\
\hline 23 & \multirow[t]{7}{*}{ Pyrochlore } & $\mathrm{Bi}_{2} \mathrm{Ce}_{2} \mathrm{O}_{7}$ & Glycine & - & $5-6$ & 15 & 49 \\
\hline 24 & & $\mathrm{Bi}_{2} \mathrm{Ti}_{2} \mathrm{O}_{7}$ & Hexamethylene-tetramine (HMT) & - & $61 \pm 35$ & 5 & 50 \\
\hline 25 & & $\mathrm{Gd}_{2} \mathrm{Ti}_{2} \mathrm{O}_{7}$ & Glycine & 29.8 & 30 & 12.5 & 51 \\
\hline 26 & & $\mathrm{Nd}_{2} \mathrm{Ti}_{2} \mathrm{O}_{7}$ & Glycine & 27.7 & 30 & 12.8 & 51 \\
\hline 27 & & $\mathrm{Er}_{2} \mathrm{Ti}_{2} \mathrm{O}_{7}$ & Glycine & 33.2 & 30 & 11.8 & 51 \\
\hline \multirow[t]{2}{*}{28} & & $\mathrm{Bi}_{2} \mathrm{Zr}_{2} \mathrm{O}_{7}$ & Urea & $4-5$ & - & 1.2 & 52 \\
\hline & & & Tartaric acid & $3-4$ & - & 2.3 & 52 \\
\hline 29 & \multirow[t]{6}{*}{ Others } & $\mathrm{Ag}_{2} \mathrm{WO}_{4}$ & Urea & 22 & 33 & 21.3 & 45 \\
\hline 30 & & $\mathrm{ZrMo}_{2} \mathrm{O}_{8}$ & Glycine & - & $40-50$ & 10 & 53 \\
\hline 31 & & $\mathrm{CuNb}_{2} \mathrm{O}_{6}$ & Urea & 20.3 & $20-60$ & 8.8 & 54 \\
\hline 32 & & $\mathrm{ZnNb}_{2} \mathrm{O}_{6}$ & Urea & 15.8 & $20-60$ & 18.4 & 54 \\
\hline 33 & & $\mathrm{ZrV}_{2} \mathrm{O}_{7}$ & Glycine & - & $30-40$ & - & 55 \\
\hline 34 & & $\mathrm{AgBiW}_{2} \mathrm{O}_{8}$ & Urea & 6 & $6.6 \pm 1.0$ & 34.4 & 56 \\
\hline
\end{tabular}


(a)

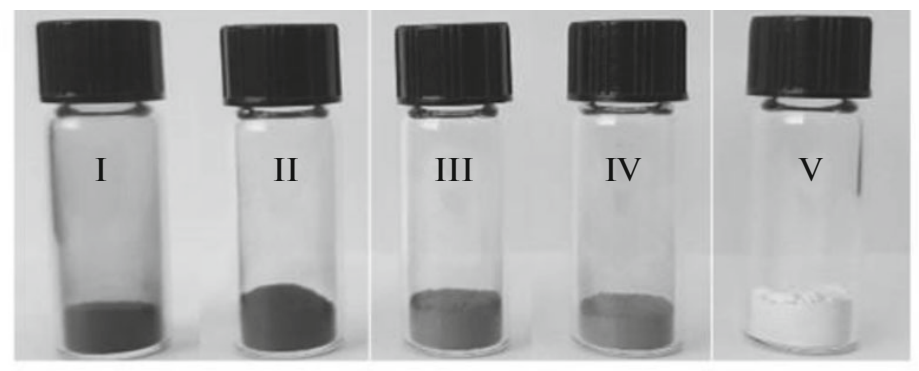

(b)

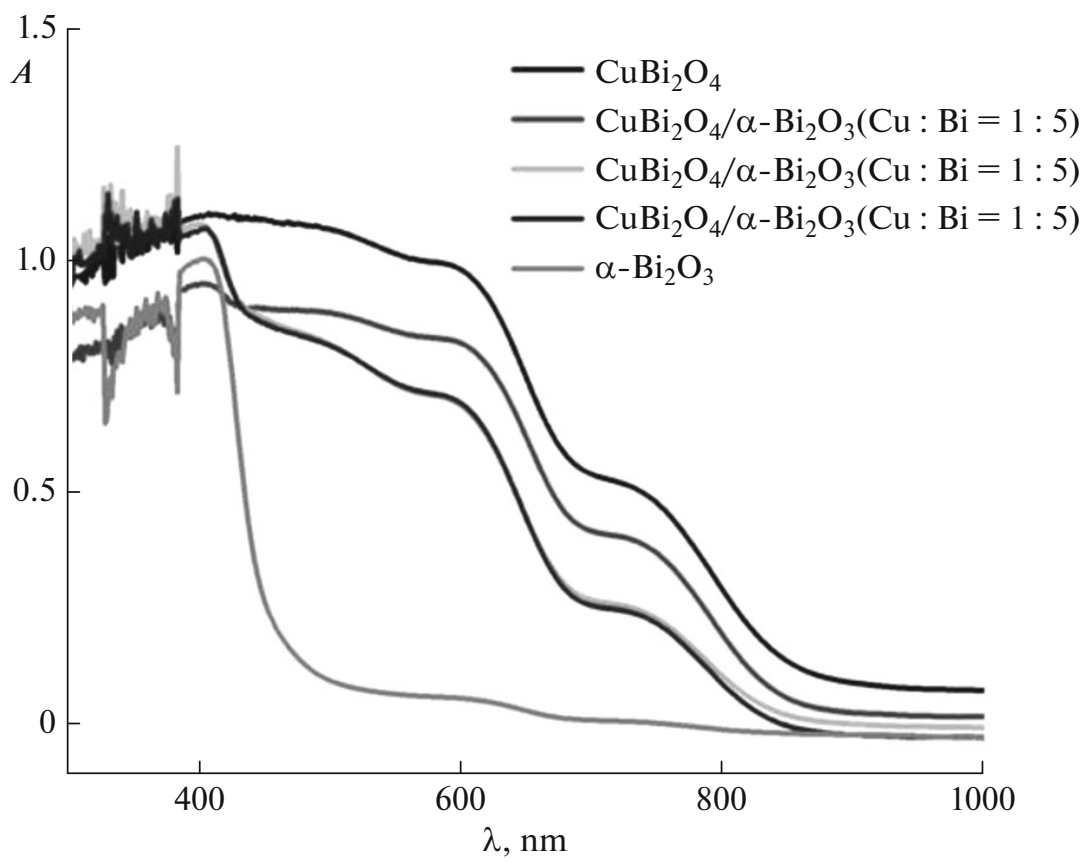

Fig. 7. (a) Change of color from pure $\mathrm{CuBi}_{2} \mathrm{O}_{4}$ (I) through $\mathrm{CuBi}_{2} \mathrm{O}_{4} / \mathrm{Bi}_{2} \mathrm{O}_{3}$ (II-IV) to pure $\mathrm{Bi}_{2} \mathrm{O}_{3}$ (V) and (b) UV-VIS absorption profiles for pure $\mathrm{CuBi}_{2} \mathrm{O}_{4}$ and $\mathrm{Bi}_{2} \mathrm{O}_{3}$ and their composites.

as their $1: 1$ ternary composition, $\mathrm{CuBi}_{2} \mathrm{O}_{4}$ were very recently synthesized using SCS. The entire gamut of composite possibilities, ranging from $\mathrm{CuO} / \mathrm{CuBi}_{2} \mathrm{O}_{4}$ composites at one end to $\mathrm{CuBi}_{2} \mathrm{O}_{4} / \mathrm{Bi}_{2} \mathrm{O}_{3}$ at the other, could be derived by tuning the SCS precursor chemistry [22]. Figure 7a shows the progressively lighter hue from pure $\mathrm{CuBi}_{2} \mathrm{O}_{4}$, the three composites, culminating in white coloration for pure $\mathrm{Bi}_{2} \mathrm{O}_{3}$. The corresponding spectral profiles are contained in Fig. $7 \mathrm{~b}$. As the $\mathrm{Bi}_{2} \mathrm{O}_{3}$ amount increased in the composites, the spectrum progressively blue-shifted (i.e. from the visible to the UV wavelength range) towards the $\mathrm{Bi}_{2} \mathrm{O}_{3}$ end.

The data in Fig. 7 signal an important hallmark of composites, namely the data signatures from them are a superposition of those corresponding to their components, and two distinct phases can be identified. In contrast, in a solid solution (or an 'alloy'), the constituents lose their individual identity via mixing at a molecular level, and resulting in a single-phase material. This happens when the ionic (or atomic) radii of the individual components are within $\sim 15 \%$ of one another such that substitution of one atom (or ion) with another at a given lattice site becomes feasible. Metal alloys are very well known and so are solid solutions of chalcogenides, phosphides, or arsenides in various technological contexts. Metal oxide solid solutions are less well studied; solid solutions of two ternary oxides are even less commonplace. This is exemplified by the $\mathrm{Cu}-\mathrm{Fe}-\mathrm{Cr}-\mathrm{O}$ system where these new materials were prepared via SCS via simple compositional tuning of the precursor mixtures [4]. Both the lattice parameter (Fig. 8) and the optical band gap value systematically varied [4], in line with Vegard's law [57]. For more details, Ref. 4 may be consulted (see e.g. Fig. 5 in it).

The phenomenon of doping largely derives its importance from the microelectronics industry. Doping refers to the controlled introduction of trace amounts of a foreign ('dopant') species into the host lattice framework. Like in the solid solution case, doping also results in a single-phase material but unlike in 


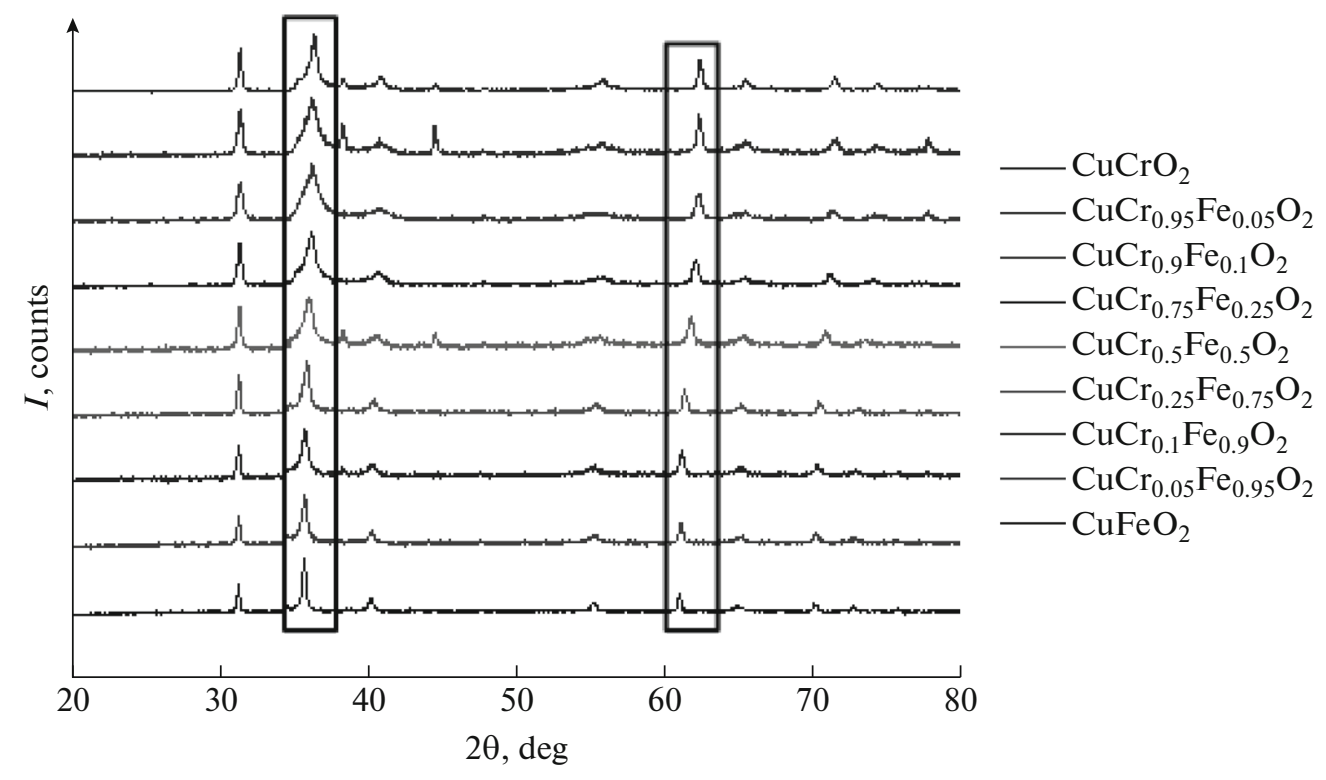

Fig. 8. XRD profiles for a series of $\mathrm{CuFeO}_{2}-\mathrm{CuCrO}_{2}$ solid solutions along with those of the two ternary end members.

a solid solution, the foreign species are present at very small levels (parts per million or less) such that perturbation of data signatures (e.g., XRD profiles) can only be resolved by careful work. On the other hand, the optoelectronic perturbations of doping are rather significant (and easily discerned) and lead to their importance in various applications. Many instances of doped metal oxide samples derived from solution combustion exist in the literature, and these will be discussed in the next and final section in this article.

\section{PHOTOELECTROCHEMICAL AND PHOTOCATALYTIC APPLICATIONS OF SCS- DERIVED COMPLEX OXIDES}

In this section, we consider how combustion synthesized complex oxides have fared in photoelectrochemical or photocatalytic applications. The distinction between the two has to do with the underlying thermodynamics of the photoconversion process. In photocatalytic processes, the radiation serves to speed up an intrinsically sluggish spontaneous reaction such as hydrocarbon (e.g., phenol) oxidation or metal ion (e.g., hexavalent chromium) reduction. On the other hand, photoelectrochemical processes such as the splitting of water (into $\mathrm{H}_{2}$ and $\mathrm{O}_{2}$ ) or the reduction of $\mathrm{CO}_{2}$ are intrinsically non-spontaneous. Table 3 compiles instances wherein combustion-synthesized ternary oxides have been deployed for the photocatalytic degradation of an organic dye. In general, the oxides derived from SCS have a higher surface area than counterparts synthesized from ceramic, solid-state reaction (SSR) routes; and this factor is reflected in the much higher photoactivity of the SCS oxides. Thus the photodegradation of $\mathrm{MB}$ using $\mathrm{SCS}-\mathrm{CuFe}{ }_{2} \mathrm{O}_{4}$ reached almost $100 \%$ in 30 min while only $25.9 \%$ was degraded using SSR sample in the similar conditions [23]. This can be rationalized on the small particle size (SCS: $100 \mathrm{~nm}$, SSR: $1-3 \mu \mathrm{m}$ ), and consequently, higher surface area of the SCS sample (SCS: $79.3 \mathrm{~m}^{2} / \mathrm{g}$, SSR: $2.2 \mathrm{~m}^{2} / \mathrm{g}$ ). A similar trend was seen for $\mathrm{SCS}-\mathrm{Bi}_{2} \mathrm{WO}_{6}$ and $\mathrm{SCS}-\mathrm{AgBiW}_{2} \mathrm{O}_{8}$ compared to their SSR counterparts [56].

Composites containing ternary oxides and prepared via SCS, have been tested for their photocatalytic dye degradation capability. Table 4 shows a list of these composites and their dye degradation capability. In all the cases, the composite outperformed its components; compare Columns 8, 9, and 10 in the compilation below.

Data are also available for doped oxides derived from SCS and their use in Photocatalytic dye degradation scenarios; Table 5 collects this corpus of data.

In contrast to the rich body of examples of photocatalytic applications, corresponding examples of photoelectrochemical water splitting or carbon dioxide reduction using SCS samples are rather limited. Although $\mathrm{BiVO}_{4}$ is primarily an oxygen evolution photocatalyst, recently, high surface area $\mathrm{BiVO}_{4}$ was synthesized using SCS and reported to be very active toward hydrogen evolution [44]. Thus, nanoparticles of SCS-BiVO ${ }_{4}$ were able to generate $195.6 \mathrm{mmol} / \mathrm{h}$ of $\mathrm{H}_{2}$ from water-ethanol mixture [44]. Pt-modified $\mathrm{SCS}-\mathrm{AgBiW} \mathrm{O}_{8}$ was investigated for the photoelectrochemical conversion of $\mathrm{CO}_{2}$ and found to be able to generate syngas from formic acid [56].

$\mathrm{LaVO}_{4} / \mathrm{BiVO}_{4}$ composites using SCS were evaluated for photoelectrochemical hydrogen generation [47]. Pristine $\mathrm{BiVO}_{4}$ did not show any $\mathrm{H}_{2}$ while $\mathrm{LaVO}_{4}$ 
Table 3. Photocatalytic dye degradation in the presence of SCS-produced ternary and quaternary oxides

\begin{tabular}{|c|c|c|c|c|c|c|c|c|}
\hline $\begin{array}{c}\text { Entry } \\
\text { no. }\end{array}$ & Oxide & Dye* & $\begin{array}{l}\text { [Dye], } \\
\mathrm{mg} / \mathrm{L}\end{array}$ & $\begin{array}{c}\text { Catal. } \\
\text { load, g/L }\end{array}$ & Light source & $\begin{array}{l}\text { Exposure } \\
\text { time, } h\end{array}$ & $\begin{array}{c}\text { Degradation, } \\
\%\end{array}$ & Refs. \\
\hline 1 & $\mathrm{CaFe}_{2} \mathrm{O}_{4}$ & MB & 3.2 & 1 & $\begin{array}{l}500 \mathrm{~W} \text { Xe lamp with } 420 \mathrm{~nm} \\
\text { cut-off filter }\end{array}$ & 0.75 & $\sim 100$ & 21 \\
\hline 2 & $\mathrm{CuFe}_{2} \mathrm{O}_{4}$ & $\begin{array}{l}\text { Rh B } \\
\text { MB } \\
\text { MO } \\
\text { Phenol }\end{array}$ & $\begin{array}{l}40 \\
40 \\
40 \\
50\end{array}$ & 0.2 & Natural sunlight & 2 & $\begin{array}{l}\sim 80 \\
\sim 75 \\
\sim 25 \\
\sim 15\end{array}$ & 23 \\
\hline 3 & $\mathrm{FeAl}_{2} \mathrm{O}_{4}$ & $\begin{array}{l}\text { MB } \\
\text { Phenol }\end{array}$ & 10 & $\begin{array}{l}1 \\
1\end{array}$ & $\begin{array}{l}350 \text { W Xe lamp with } 400 \mathrm{~nm} \\
\text { cut-off filter }\end{array}$ & $\begin{array}{l}2.5 \\
4\end{array}$ & $\begin{array}{l}\sim 70 \\
\sim 50\end{array}$ & 24 \\
\hline 4 & $\mathrm{MgAl}_{2} \mathrm{O}_{4}$ & $\mathrm{MB}$ & 10 & 0.75 & $\begin{array}{l}350 \text { W Xe lamp with } 400 \mathrm{~nm} \\
\text { cut-off }\end{array}$ & 0.75 & $\sim 85$ & 26 \\
\hline 5 & $\mathrm{MgFe}_{2} \mathrm{O}_{4}$ & MY & 20 & 0.16 & $350 \mathrm{~W}$ Xe lamp & 1 & $\sim 65$ & 27 \\
\hline 6 & $\mathrm{MnFe}_{2} \mathrm{O}_{4}$ & MG & 20 & 0.24 & Natural sunlight & 2 & $\sim 65$ & 28 \\
\hline 7 & $\mathrm{NiFe}_{2} \mathrm{O}_{4}$ & MB & 20 & 0.25 & 300W Xe lamp & 2 & $\sim 65$ & 29 \\
\hline 8 & $\mathrm{ZnFe}_{2} \mathrm{O}_{4}$ & $\begin{array}{l}\mathrm{Rh} B \\
\mathrm{CR}\end{array}$ & $\begin{array}{l}5 \\
10\end{array}$ & 1 & Natural sunlight & $\begin{array}{l}1 \\
0.5\end{array}$ & $\begin{array}{l}\sim 94 \\
\sim 95\end{array}$ & 31 \\
\hline 9 & $\mathrm{GdFeO}_{3}$ & $\mathrm{Rh} B$ & 4.8 & 1 & $500 \mathrm{~W}$ Xe lamp & 2 & $\sim 40$ & 32 \\
\hline 11 & $\mathrm{LaNiO}_{3}$ & MO & 10 & 2 & 400W Xe lamp & 5 & $\sim 75$ & 35 \\
\hline 12 & $\mathrm{SrTiO}_{3}$ & MO & 5 & 0.3 & 16 W UV lamp & 3 & $\sim 8$ & 36 \\
\hline 13 & $\mathrm{YFeO}_{3}$ & $\begin{array}{l}\text { MB } \\
\text { Rh B }\end{array}$ & $\begin{array}{l}32 \\
10\end{array}$ & $\begin{array}{l}1 \\
1\end{array}$ & $\begin{array}{l}300 \mathrm{~W} \text { tungsten halogen lamp } \\
175 \mathrm{~W} \text { metal halide lamp with } \\
420 \mathrm{~nm} \text { cut-off filter }\end{array}$ & $\begin{array}{l}4 \\
3\end{array}$ & $\begin{array}{l}\sim 70 \\
\sim 70\end{array}$ & $\begin{array}{l}37 \\
38\end{array}$ \\
\hline 14 & $\mathrm{Bi}_{2} \mathrm{MoO}_{6}$ & Rh B & 10 & 1 & Natural sunlight & 5 & $\sim 100$ & 39 \\
\hline 15 & $\mathrm{Bi}_{2} \mathrm{WO}_{6}$ & $\mathrm{Rh} B$ & 47.9 & 1 & 500W Xe lamp & 1.25 & $\sim 100$ & 40 \\
\hline 16 & $\mathrm{BiVO}_{4}$ & $\begin{array}{l}\text { MO } \\
\text { MB } \\
\text { Rh B } \\
\text { MB }\end{array}$ & $\begin{array}{l}32.8 \\
639.7 \\
5 \\
20\end{array}$ & $\begin{array}{l}2 \\
0.05 \\
1 \\
2\end{array}$ & $\begin{array}{l}450 \mathrm{~W} \text { tungsten-halogen lamp } \\
500 \mathrm{~W} \text { Xe lamp } \\
\text { Xe lamp of } 6000 \mathrm{~K} \\
\text { Natural sunlight }\end{array}$ & $\begin{array}{l}4 \\
3 \\
3 \\
1\end{array}$ & $\begin{array}{l}\sim 65 \\
\sim 70 \\
\sim 100 \\
\sim 100\end{array}$ & $\begin{array}{l}41 \\
42 \\
43 \\
44\end{array}$ \\
\hline 17 & $\mathrm{CuWO}_{4}$ & MO & 16.4 & 2 & 400W medium pressure $\mathrm{Hg}$ arc & 1.33 & $\sim 100$ & 45 \\
\hline 18 & $\mathrm{ZnWO}_{4}$ & $\begin{array}{l}\text { MO } \\
\text { MB }\end{array}$ & $\begin{array}{l}16.4 \\
5\end{array}$ & $\begin{array}{l}2 \\
0.8\end{array}$ & $\begin{array}{l}\text { 400W medium pressure } \mathrm{Hg} \text { arc } \\
125 \mathrm{~W} \text { Hg lamp }\end{array}$ & $\begin{array}{l}1 \\
3\end{array}$ & $\begin{array}{l}\sim 100 \\
\sim 75\end{array}$ & 46 \\
\hline 19 & $\mathrm{CeVO}_{4}$ & OG & 50 & 1 & 125 W high pressure Hg lamp & 0.5 & $\sim 40$ & 47 \\
\hline 20 & $\mathrm{Ag}_{2} \mathrm{WO}_{4}$ & MO & 16.4 & 2 & $400 \mathrm{~W}$ medium pressure $\mathrm{Hg}$ arc & 1 & $\sim 90$ & 45 \\
\hline 21 & $\mathrm{Bi}_{2} \mathrm{Ce}_{2} \mathrm{O}_{7}$ & MG & 45 & 1 & Natural sunlight & 5 & $\sim 100$ & 49 \\
\hline 22 & $\mathrm{Bi}_{2} \mathrm{Ti}_{2} \mathrm{O}_{7}$ & MO & 16.4 & 2 & 150W medium pressure $\mathrm{Hg}$ arc & 2 & $\sim 95$ & 50 \\
\hline 23 & $\mathrm{Gd}_{2} \mathrm{Ti}_{2} \mathrm{O}_{7}$ & MO & 5 & 1 & Four 4 W UV lamps & 2 & $\sim 97$ & 51 \\
\hline 24 & $\mathrm{Nd}_{2} \mathrm{Ti}_{2} \mathrm{O}_{7}$ & MO & 5 & 1 & Four 4 W UV lamps & 2 & $\sim 50$ & \\
\hline 25 & $\mathrm{Er}_{2} \mathrm{Ti}_{2} \mathrm{O}_{7}$ & MO & 5 & 1 & Four 4 W UV lamps & 2 & $\sim 89$ & \\
\hline 26 & $\mathrm{Bi}_{2} \mathrm{Zr}_{2} \mathrm{O}_{7}$ & $\begin{array}{l}\text { RBBR } \\
\text { IC } \\
\text { RBBR } \\
\text { IC }\end{array}$ & & 1 & Natural sunlight $\left(800 \mathrm{~W} \mathrm{~m}^{-2}\right)$ & 5 & $\begin{array}{l}\sim 70 \\
\sim 100 \\
\sim 35 \\
\sim 60\end{array}$ & 52 \\
\hline 27 & $\mathrm{ZrMo}_{2} \mathrm{O}_{8}$ & $\mathrm{Rh} B$ & 15 & 1 & $125 \mathrm{~W}$ high pressure Hg lamp & 2 & $\sim 40$ & 53 \\
\hline 28 & $\mathrm{ZrV}_{2} \mathrm{O}_{7}$ & $\mathrm{Rh} B$ & 20 & 1 & $125 \mathrm{~W}$ high pressure $\mathrm{Hg}$ lamp & 1 & $\sim 40$ & 55 \\
\hline 29 & $\mathrm{AgBiW}_{2} \mathrm{O}_{8}$ & MO & 16.4 & 2 & $\begin{array}{l}400 \mathrm{~W} \text { medium-pressure } \mathrm{Hg} \\
\text { arc }\end{array}$ & 6 & $\sim 95$ & 56 \\
\hline
\end{tabular}

*Notes. MO stands for Methyl Orange, MG Malachite Green, RBBR Ramazoline Brilliant Blue, MB Methylene Blue, CR Congo Red, MY Metanil Yellow, Rh B Rhodamine B, IC Indigo Carmine, OG Orange Green. 
Table 4. Composite oxides with improved dye degradation performance

\begin{tabular}{|c|c|c|c|c|c|c|c|c|c|c|}
\hline \multirow{2}{*}{$\begin{array}{c}\text { Entry } \\
\text { no. }\end{array}$} & \multirow[b]{2}{*}{ Composite } & \multirow[b]{2}{*}{ Dye } & \multirow{2}{*}{$\begin{array}{l}\text { [Dye] } \\
\mathrm{mg} / \mathrm{L}\end{array}$} & \multirow{2}{*}{$\begin{array}{l}\text { Catal. load, } \\
\text { g/L }\end{array}$} & \multirow[b]{2}{*}{ Light source } & \multirow{2}{*}{$\begin{array}{l}\text { Expos. } \\
\text { time, h }\end{array}$} & \multicolumn{3}{|c|}{ Degradation (\%) } & \multirow[b]{2}{*}{ Refs. } \\
\hline & & & & & & & $\begin{array}{c}\text { Comp. } \\
\text { I }\end{array}$ & $\begin{array}{c}\text { Comp. } \\
\text { II }\end{array}$ & Total & \\
\hline 1 & $\mathrm{Bi}_{2} \mathrm{O}_{3} / \mathrm{Bi}_{2} \mathrm{WO}_{6}$ & $\mathrm{Rh} B$ & 47.9 & 1 & $500 \mathrm{~W}$ Xe lamp & 0.5 & $\sim 1.5$ & $\sim 61$ & $\sim 98$ & 58 \\
\hline 2 & $\mathrm{BiVO}_{4} / \mathrm{BiOCl}$ & $\mathrm{Rh} B$ & 20 & 1 & 300 W Xe lamp & 3 & $\sim 8$ & $\sim 38$ & $\sim 85$ & 59 \\
\hline 3 & $\mathrm{CuO} / \mathrm{BiVO}_{4}$ & MB & 639.7 & 0.05 & 500 W Xe lamp & 3 & - & $\sim 28$ & $\sim 47$ & 60 \\
\hline 4 & $\begin{array}{l}\mathrm{NiFe}_{2} \mathrm{O}_{4} / \mathrm{BiO} \\
\mathrm{Br}\end{array}$ & $\mathrm{Rh} B$ & 10 & 1 & 300 W Xe lamp & 2 & $\sim 31$ & $\sim 46$ & $\sim 96$ & 61 \\
\hline 5 & $\mathrm{~V}_{2} \mathrm{O}_{5} / \mathrm{BiVO}_{4}$ & MB & 639.7 & 0.05 & 500 W Xe lamp & 3 & $\sim 58$ & $\sim 37$ & $\sim 83$ & 62 \\
\hline
\end{tabular}

Table 5. Photocatalytic degradation of organic dyes in the presence of doped ternary oxides

\begin{tabular}{|c|c|c|c|c|c|c|c|c|c|}
\hline \multirow{2}{*}{$\begin{array}{l}\text { Entry } \\
\text { no. }\end{array}$} & \multirow[b]{2}{*}{ Oxide } & \multirow[b]{2}{*}{ Dopant } & \multirow[b]{2}{*}{ Dye } & \multirow{2}{*}{$\begin{array}{c}\text { [Dye], } \\
\text { mg/L }\end{array}$} & \multirow{2}{*}{$\begin{array}{l}\text { Catal. load, } \\
\text { g/L }\end{array}$} & \multirow[b]{2}{*}{ Light source } & \multicolumn{2}{|c|}{ Degradation, $\%$} & \multirow[b]{2}{*}{ Refs. } \\
\hline & & & & & & & $\begin{array}{l}\text { Pristine } \\
\text { oxide }\end{array}$ & $\begin{array}{l}\text { Doped } \\
\text { oxide }\end{array}$ & \\
\hline 1 & $\mathrm{MgFe}_{2} \mathrm{O}_{4}$ & $\mathrm{Ag}$ & MY & 20 & 0.16 & $350 \mathrm{~W}$ Xe-lamp & $\sim 65$ & $\sim 89$ & 27 \\
\hline 2 & $\mathrm{MnFe}_{2} \mathrm{O}_{4}$ & $\mathrm{Cu}$ & MG & 20 & 0.24 & Natural sunlight & $\sim 65$ & $\sim 92$ & 28 \\
\hline 3 & $\mathrm{NiFe}_{2} \mathrm{O}_{4}$ & $\mathrm{Ag}$ & MB & 20 & 0.25 & 300 W Xe lamp & $\sim 50$ & $\sim 65$ & 29 \\
\hline 4 & $\mathrm{SrTiO}_{3}$ & $\mathrm{~Pb}$ & MO & 5 & 0.3 & 16 W UV lamp & $\sim 8$ & $\sim 85$ & 36 \\
\hline 5 & $\mathrm{LaFeO}_{3}$ & Mn & MO & 100 & 7.3 & Natural sunlight & - & $\sim 87$ & 63 \\
\hline 6 & $\mathrm{ZnWO}_{4}$ & $\mathrm{Eu}$ & Rh B & 4.8 & 1 & Four 4 W UV lamps & $\sim 70$ & -85 & 64 \\
\hline 7 & $\mathrm{CeVO}_{4}$ & $\mathrm{Pd}$ & OG & 50 & 1 & 125 W high-press. Hg lamp & $\sim 40$ & $\sim 65$ & 48 \\
\hline 9 & $\mathrm{ZrV}_{2} \mathrm{O}_{7}$ & Mo & Rh B & 20 & 1 & $125 \mathrm{~W}$ high- press Hg lamp & $\sim 40$ & $\sim 80$ & 55 \\
\hline
\end{tabular}

showed an $\mathrm{H}_{2}$ photogeneration rate of $24 \mu \mathrm{mol} \mathrm{h}^{-1}$. On the other hand, $20 \%$ loading of $\mathrm{BiVO}_{4}$ in $\mathrm{LaVO}_{4} / \mathrm{BiVO}_{4}$ composite showed $45.5 \mu \mathrm{mol} \mathrm{h}^{-1}$ [47]. High resolution TEM images showed intimate physical contact of $\mathrm{LaVO}_{4}$ and $\mathrm{BiVO}_{4}$ in the composite matrix facilitating vectorial charge transport and thus enhancing the photoelectrochemical activity.

\section{CONCLUSIONS}

The examples given above in this perspective article ought to have amply demonstrated the virtues of combustion synthesis as a viable technique for the preparation of complex oxides for photoelectrochemical and photocatalytic applications. While serving as a useful review for seasoned practitioners, hopefully, this article will be helpful to new entrants to this field as a sampling of the exciting possibilities ahead in materials discovery and use.

\section{ACKNOWLEDGMENTS}

K.R. and M.K.H. thank the University of Texas at Arlington for partial support of this research project. C.J. and his team thank the support from the Széchenyi 2020 program in the framework of GINOP-2.3.2-15-2016-00013. E. K. acknowledges the support of the New National Excellence Program of the Ministry of Human Capacities (Grant UNKP17-3). We also thank an anonymous reviewer for constructive criticism of an earlier manuscript version.

\section{REFERENCES}

1. Kobayashi, Y., Yoshihiro, T., and Kageyama, H., Property engineering in perovskites via modification of anion chemistry, Annu. Rev. Mater. Sci., 2018, vol. 48.

2. Kageyama, H., Hayashi, K., Maeda, K., Attfield, J.P., Hiroi, Z., Rondinelli, J., and Poeppelmeir, K.R., Expanding frontiers in materials chemistry and physics with multiple anions, Nature Commun., 2018, vol. 9, article number 772 .

3. McCarroll, W.H. and Ramanujachary, K.V., Encycolpaedia of Inorganic Chemistry, Ch. 3: Oxides: Solid State Chemistry, New York: Wiley, 2006.

4. Rajeshwar, K., Hossain, M.K., Macaluso, R.T., Janaky, C., Varga, A., and Kulesza, P.J., Copper oxidebased ternary and quaternary oxides: Where solid-state chemistry meets photoelectrochemistry (Review), $J$. Electrochem. Soc., 2018, vol. 165, pp. H3192-H3206.

5. Rajeshwar, K., Toward a renewable energy future, in Solar Hydrogen Generation, Rajeshwar, K., McConnell, R., and Licht, S., Eds., New York: Academic, 2008, pp. 167-228.

6. Rajeshwar, K., Solar energy conversion and environmental remediation using inorganic semiconductorliquid interfaces: The road traveled and the way forward, J. Phys. Chem. Lett., 2011, vol. 2, pp. 1301-1309. 
7. Rajeshwar, K., Photoelectrochemistry and the environment, J. Appl. Electrochem., 1995, vol. 25, pp. 10671082.

8. Bard, A.J. and Fox, M.A., Artificial photosynthesis: Solar splitting of water to hydrogen and oxygen, Acc. Chem. Res., 1995, vol. 28, pp. 141-145.

9. Wen, W. and Wu, J.M., Nanomaterials via solution combustion synthesis: A step nearer to controllability, RSC Adv., 2014, vol. 4, pp. 58090-58100.

10. Mukasyan, A.S., Epstein, P., and Dinka, P., Solution combustion synthesis of nanomaterials, Proc. Combust. Inst., 2007, vol. 31, pp. 1789-1795.

11. Aruna, S.T. and Mukasyan, A.S., Combustion synthesis and nanomaterials, Curr. Opin. Solid State Mater. Sci., 2008, vol. 12, pp. 44-50.

12. Varma, A., Mukasyan, A.S., Rogachev, A.S., and Manukyan, K.V., Solution combustion synthesis of nanoscale materials, Chem. Rev., 2016, vol. 116, pp. 14493-14586.

13. Li, F.T., Ran, J., Jaroniec, M., and Qiao, S.Z., Solution combustion synthesis of metal oxide nanomaterials for energy storage and conversion, Nanoscale, 2015, vol. 7, pp. 17590-17610.

14. Hegde, M.S., Madras, G., and Patil, K.C., Noble metal ionic catalysts, Acc. Chem. Res., 2009, vol. 42, pp. 704-712.

15. González-Cortés, S.L. and Imbert, F.E., Fundamentals, properties and applications of solid catalysts prepared by solution combustion synthesis (SCS), Appl. Catal., A, 2013, vol. 452, pp. 117-131.

16. Rajeshwar, K. and de Tacconi, N.R., Solution combustion synthesis of oxide semiconductors for solar energy conversion and environmental remediation, Chem. Soc. Rev., 2009, vol. 38, no. 7, pp. 1984-1998.

17. Patil, K.C., Hegde, M.S., Yanu, R., and Aruna, S.T., Chemistry of Nanocrystalline Oxide Materials: Combustion Synthesis, Properties and Applications, Singapore: World Scientific, 2008.

18. Yu, X., Smith, J., Zhou, N., Zeng, L., Guo, P., Xia, Y., Alvarez, A., Aghion, S., Lin, H., Yu, J., Chang, R.P., Bedzyk, M.J., Ferragut, R., Marks, T.J., and Facchetti, A., Spray- combustion synthesis: Efficient solution route to high-performance oxide transistors, Proc. Natl. Acad. Sci. USA, 2015, vol. 112, pp. 3217-3222.

19. Mukasyan, A.S. and Dinka, P., Novel approaches to solution-combustion synthesis of nanomaterials, Int. J. Self-Propag. High-Temp. Synth., 2007, vol. 16, no. 1, pp. 23-35.

20. Akopdzhanyan, T.G. and Borovinskaya, I.P., AlON powders by SHS under nitrogen pressure with $\mathrm{KClO}_{4}$ as a booster, Int. J. Self-Propag. High-Temp. Synth., 2017, vol. 26, no. 4. pp. 244-247.

21. Zhang, Z. and Wang, W., Solution combustion synthesis of $\mathrm{CaFe}_{2} \mathrm{O}_{4}$ nanocrystal as a magnetically separable photocatalyst, Mater. Lett., 2014, vol. 133, pp. 212-215.

22. Hossain, M.K., Samu, G.F., Gandha, K., Santhanagopalan, S., Liu, J.P., Janáky, C., and Rajeshwar, K., Solution combustion synthesis, characterization, and photocatalytic activity of $\mathrm{CuBi}_{2} \mathrm{O}_{4}$ and its nanocomposites with $\mathrm{CuO}$ and $\alpha-\mathrm{Bi}_{2} \mathrm{O}_{3}, J$. Phys. Chem. C, 2017, vol. 121 , pp. 8252-6261.

23. Kumar, A., Rout, L., Achary, L.S.K., Mohanty, S.K. and Dash, P., A combustion synthesis route for magnetically separable graphene oxide- $-\mathrm{CuFe}_{2} \mathrm{O}_{4}-\mathrm{ZnO}$ nanocomposites with enhanced solar light-mediated photocatalytic activity, New J. Chem., 2017, vol. 41, pp. 10568-10583.

24. Chai, M.J., Chen, X.M., Zhao, Y., Liu, R.H., Zhao, J., and $\mathrm{Li}$, F.T., Facile ionic liquid combustion synthesis and visible-light photocatalytic ability of mesoporous $\mathrm{FeAl}_{2} \mathrm{O}_{4}$ with high specific surface area, Chem. Lett., 2014, vol. 43, pp. 1743-1745.

25. Mu, H.Y., Li, F.T., An, X.T., Liu, R.H., Li, Y.L., Qian, X., and $\mathrm{Hu}, \mathrm{Y} . \mathrm{Q}$. , One-step synthesis, electronic structure, and photocatalytic activity of earth-abundant visiblelight- driven $\mathrm{FeAl}_{2} \mathrm{O}_{4}$, Phys. Chem. Chem. Phys., 2017, vol. 19, pp. 9392-9401.

26. Li, F.T., Zhao, Y., Liu, Y., Hao, Y.J., Liu, R.H., and Zhao, D.S., Solution combustion synthesis and visible light-induced photocatalytic activity of mixed amorphous and crystalline $\mathrm{MgAl}_{2} \mathrm{O}_{4}$ nanopowders, Chem. Eng. J., 2011, vol. 173, pp. 750-759.

27. Shetty, K., Prathibha, B.S., Rangappa, D., Anantharaju, K.S., Nagaswarupa, H.P., Nagabhushana, H., and Prashantha, S.C., Photocatalytic study for fabricated $\mathrm{Ag}$ doped and undoped $\mathrm{MgFe}_{2} \mathrm{O}_{4}$ nanoparticles, Mater. Today, 2017, vol. 4, no. 11, pp. 11764-11772.

28. Meena, S., Renuka, L., Anantharaju, K.S., Vidya, Y.S., Nagaswarupa, H.P., Prashantha, S.C., and Nagabhushana, H., Optical, electrochemical and photocatalytic properties of sunlight driven $\mathrm{Cu}$ doped manganese ferrite synthesized by solution combustion synthesis, Mater. Today, 2017, vol. 4, no. 11, pp. 11773-11781.

29. Zhang, D., Pu, X., Du, K., Yu, Y.M., Shim, J.J., Cai, P., Kim, S.I., and Seo, H.J., Combustion synthesis of magnetic $\mathrm{Ag} / \mathrm{NiFe}_{2} \mathrm{O}_{4}$ composites with enhanced visible-light photocatalytic properties, Sep. Purif. Technol., 2014, vol. 137, pp. 82-85.

30. Kelkar, S.A., Shaikh, P.A., Pachfule, P., and Ogale, S.B., Nanostructured $\mathrm{Cd}_{2} \mathrm{SnO}_{4}$ as an energy harvesting photoanode for solar water splitting, Energy Environ. Sci., 2012, vol. 5, no. 2, pp. 5681-5685.

31. Behera, A., Kandi, D., Majhi, S.M., Martha, S., and Parida, K., Facile synthesis of $\mathrm{ZnFe}_{2} \mathrm{O}_{4}$ photocatalysts for decolorization of organic dyes under solar irradiation, Beilstein J. Nanotechnol., 2018, vol. 9, pp. 436446.

32. Li, L. and Wang, X., Self-propagating combustion synthesis and synergistic photocatalytic activity of $\mathrm{GdFeO}_{3}$ nanoparticles, J. Sol-Gel Sci. Technol., 2016, vol. 79, pp. 107-113.

33. Parida, K.M., Reddy, K.H., Martha, S., Das, D.P., and Biswal, N., Fabrication of nanocrystalline $\mathrm{LaFeO}_{3}$ : An efficient sol-gel auto-combustion assisted visible light responsive photocatalyst for water decomposition, Int. J. Hydrogen Energy, 2010, vol. 35, pp. 12161-12168.

34. Li, F.T., Liu, Y., Sun, Z.M., Liu, R.H., Kou, C.G., Zhao, Y. and Zhao, D.S., Facile preparation of porous $\mathrm{LaFeO}_{3}$ nanomaterial by self-combustion of ionic liquids, Mater. Lett., 2011, vol. 65, pp. 406-408.

35. Li, Y., Yao, S., Wen, W., Xue, L., and Yan, Y., Sol-gel combustion synthesis and visible-light-driven photocatalytic property of perovskite $\mathrm{LaNiO}_{3}$, J. Alloys Compd., 2010, vol. 491, pp. 560-564.

36. Xue, H., Li, Z., Wang, X., and Fu, X., Studies on nanocrystalline $(\mathrm{Sr}, \mathrm{Pb}) \mathrm{TiO}_{3}$ solid solutions prepared via a facile self-propagating combustion method, J. Phys. Chem. Solids, 2007, vol. 68, pp. 2326-2331. 
37. Wu, L., Jimmy, C.Y., Zhang, L., Wang, X., and Li, S., Selective self-propagating combustion synthesis of hexagonal and orthorhombic nanocrystalline yttrium iron oxide, J. Solid State Chem., 2004, vol. 177, no. 10, pp. 3666-3674.

38. Chen, Y., Yang, J., Wang, X., Feng, F., Zhang, Y., and Tang, Y., Synthesis $\mathrm{YFeO}_{3}$ by salt-assisted solution combustion method and its photocatalytic activity, $J$. Ceram. Soc. Jpn., 2014, vol. 122, pp. 146-150.

39. Saha, D., Madras, G., and Row, T.G., Solution combustion synthesis of $\gamma(\mathrm{L})-\mathrm{Bi}_{2} \mathrm{MoO}_{6}$ and photocatalytic activity under solar radiation, Mater. Res. Bull., 2011, vol. 46, pp. 1252-1256.

40. Zhang, Z., Wang, W., Shang, M., and Yin, W., Lowtemperature combustion synthesis of $\mathrm{Bi}_{2} \mathrm{WO}_{6}$ nanoparticles as a visible-light-driven photocatalyst, J. Hazard. Mater., 2010, vol. 177, pp. 1013-1018.

41. Timmaji, H.K., Chanmanee, W., de Tacconi, N.R., and Rajeshwar, K., Solution combustion synthesis of $\mathrm{BiVO}_{4}$ nanoparticles: Effect of combustion precursors on the photocatalytic activity, J. Adv. Oxid. Technol., 2011, vol. 14, pp. 93-105.

42. Jiang, H.Q., Endo, H., Natori, H., Nagai, M., and Kobayashi, K., Fabrication and photoactivities of spherical-shaped $\mathrm{BiVO}_{4}$ photocatalysts through solution combustion synthesis method, J. Eur. Ceram. Soc., 2008, vol. 28, pp. 2955-2962.

43. Pérez, U.G., Sepúlveda-Guzmán, S., Martínez-de la Cruz, A., and Méndez, U.O., Photocatalytic activity of $\mathrm{BiVO}_{4}$ nanospheres obtained by solution combustion synthesis using sodium carboxymethylcellulose, $\mathrm{J}$. Mol. Catal. A: Chem., 2011, vol. 335, pp. 169-175.

44. Nagabhushana, G.P., Nagaraju, G., and Chandrappa, G.T., Synthesis of bismuth vanadate: Its application in $\mathrm{H}_{2}$ evolution and sunlight-driven photodegradation, J. Mater. Chem. A, 2013, vol. 1, pp. 388-394.

45. Thomas, A., Janáky, C., Samu, G.F., Huda, M.N., Sarker, P., Liu, J. P., Van Nguyen, V., Wang, E.H., Schug, K.A., and Rajeshwar, K., Time-and energyefficient solution combustion synthesis of binary metal tungstate nanoparticles with enhanced photocatalytic activity, ChemSusChem, 2015, vol. 8, pp. 1652-1663.

46. Eranjaneya, H. and Chandrappa, G.T., Solution combustion synthesis of nano $\mathrm{ZnWO}_{4}$ photocatalyst, Trans. Indian Ceram. Soc., 2016, vol. 75, pp. 133-137.

47. Veldurthi, N.K., Eswar, N.K., Singh, S.A., and Madras, G., Cocatalyst free $\mathrm{Z}$-schematic enhanced $\mathrm{H}_{2}$ evolution over $\mathrm{LaVO}_{4} / \mathrm{BiVO}_{4}$ composite photocatalyst using $\mathrm{Ag}$ as an electron mediator, Appl. Catal., B, 2018, vol. 220, pp. 512-523.

48. Bellakki, M.B., Baidya, T., Shivakumara, C., Vasanthacharya, N.Y., Hegde, M.S., and Madras, G., Synthesis, characterization, redox and photocatalytic properties of $\mathrm{Ce}_{1-x} \mathrm{Pd}_{x} \mathrm{VO}_{4}(0 \leq x \leq 0.1)$, Appl. Catal., B, 2008, vol. 84, pp. 474-481.

49. Saha, D., Madras, G., and Row, T.N.G., Synthesis and structure of $\mathrm{Bi}_{2} \mathrm{Ce}_{2} \mathrm{O}_{7}$ : A new compound exhibiting high solar photocatalytic activity, Dalton Trans., 2012, vol. 41, pp. 9598-9600.

50. Samu, G.F., Veres, Á., Endrődi, B., Varga, E., Rajeshwar, K., and Janáky, C., Bandgap-engineered quaternary $\mathrm{M}_{x} \mathrm{Bi}_{2-x} \mathrm{Ti}_{2} \mathrm{O}_{7} \quad(\mathrm{M}: \mathrm{Fe}, \mathrm{Mn})$ semiconductor nanoparticles: Solution combustion synthesis, characterization, and photocatalysis, Appl. Catal., B, 2017, vol. 208, pp. 148-160.
51. Xue, H., Zhang, Y., Xu, J., Liu, X., Qian, Q., Xiao, L., and Chen, Q., Facile one-pot synthesis of porous $\mathrm{Ln}_{2} \mathrm{Ti}_{2} \mathrm{O}_{7}$ $(\mathrm{Ln}=\mathrm{Nd}, \mathrm{Gd}, \mathrm{Er})$ with photocatalytic degradation performance for methyl orange, Catal. Commun., 2014, vol. 51, pp. 72-76.

52. Sharma, V.M., Saha, D., Madras, G., and Row, T.G., Synthesis, structure, characterization and photocatalytic activity of $\mathrm{Bi}_{2} \mathrm{Zr}_{2} \mathrm{O}_{7}$ under solar radiation, $R S C$ Adv., 2013, vol. 3, pp. 18938-18943.

53. Sahoo, P.P., Madras, G., and Guru Row, T.N., Synthesis, characterization, and photocatalytic properties of $\mathrm{ZrMo}_{2} \mathrm{O}_{8}$, J. Phys. Chem. C, 2009, vol. 113, pp. 10661-10666.

54. Kormányos, A., Thomas, A., Huda, M.N., Sarker, P., Liu, J.P., Poudyal, N., Janáky, C., and Rajeshwar, K., Solution combustion synthesis, characterization, and photoelectrochemistry of $\mathrm{CuNb}_{2} \mathrm{O}_{6}$ and $\mathrm{ZnNb}_{2} \mathrm{O}_{6}$ nanoparticles, J. Phys. Chem. C, 2016, vol. 120, pp. 16024-16034.

55. Sahoo, P.P., Sumithra, S., Madras, G., and Guru Row, T.N., Synthesis, structure, negative thermal expansion, and photocatalytic property of Mo doped $\mathrm{ZrV}_{2} \mathrm{O}_{7}$, Inorg. Chem., 2011, vol. 50, pp. 8774-8781.

56. de Tacconi, N.R., Timmaji, H.K., Chanmanee, W., Huda, M.N., Sarker, P., Janáky, C., and Rajeshwar, K., Photocatalytic generation of syngas using combustionsynthesized silver bismuth tungstate, Chem. Phys. Chem., 2012, vol. 13, pp. 2945-2955.

57. Vegard, L., Die Konstitution der Mischkristalle und die Raumfüllung der Atome, Z. Phys., 1921, vol. 5, pp. 1726.

58. Hao, Y.J., Li, F.T., Chen, F., Chai, M.J., Liu, R.H. and Wang, X.J., In situ one-step combustion synthesis of $\mathrm{Bi}_{2} \mathrm{O}_{3} / \mathrm{Bi}_{2} \mathrm{WO}_{6}$ heterojunctions with notable visible light photocatalytic activities, Mater. Lett., 2014, vol. 124, pp. 1-3.

59. Lv, D., Zhang, D., Pu, X., Kong, D., Lu, Z., Shao, X., Ma, H., and Dou, J., One-pot combustion synthesis of $\mathrm{BiVO}_{4} / \mathrm{BiOCl}$ composites with enhanced visible-light photocatalytic properties, Sep. Purif. Technol., 2017, vol. 174, pp. 97-103.

60. Jiang, H.Q., Endo, H., Natori, H., Nagai, M., and Kobayashi, K., Fabrication and efficient photocatalytic degradation of methylene blue over $\mathrm{CuO} / \mathrm{BiVO}_{4}$ composite under visible-light irradiation, Mater. Res. Bull., 2009, vol. 44, pp. 700-706.

61. Lu, D., Zhang, D., Liu, X., Liu, Z., Hu, L., Pu, X., $\mathrm{Ma}, \mathrm{H}$., Li, D., and Dou, J., Magnetic $\mathrm{NiFe}_{2} \mathrm{O}_{4} / \mathrm{BiOBr}$ composites: One-pot combustion synthesis and enhanced visible-light photocatalytic properties, Sep. Purif. Technol., 2016, vol. 158, pp. 302-307.

62. Jiang, H., Nagai, M., and Kobayashi, K., Enhanced photocatalytic activity for degradation of methylene blue over $\mathrm{V}_{2} \mathrm{O}_{5} / \mathrm{BiVO}_{4}$ composite, J. Alloys Compd., 2009, vol. 479, pp. 821-827.

63. Wei, Z.X., Wang, Y., Liu, J.P., Xiao, C.M., and Zeng, W.W., Synthesis, magnetization and photocatalytic activity of $\mathrm{LaFeO}_{3}$ and $\mathrm{LaFe}_{0.5} \mathrm{Mn}_{0.5-x} \mathrm{O}_{3-\delta}$, Mater. Chem. Phys., 2012, vol. 136, pp. 755-761.

64. Dong, T., Li, Z., Ding, Z., Wu, L., Wang, X., and Fu, X., Characterizations and properties of $\mathrm{Eu}^{3+}$-doped $\mathrm{ZnWO}_{4}$ prepared via a facile self-propagating combustion method, Mater. Res. Bull., 2008, vol. 43, pp. 16941701 . 